\title{
Thermotoga hypogea sp. nov., a Xylanolytic, Thermophilic Bacterium from an Oil-Producing Well
}

\author{
M.-L. FARDEAU, ${ }^{1}$ B. OLLIVIER, ${ }^{1 *}$ B. K. C. PATEL,${ }^{2}$ M. MAGOT, ${ }^{3}$ P. THOMAS,${ }^{4}$ A. RIMBAULT, 5 \\ F. ROCCHICCIOLI, ${ }^{6}$ AND J.-L. GARCIA ${ }^{1}$ \\ Laboratoire ORSTOM de Microbiologie des Anaérobies, Université de Provence, ${ }^{1}$ and Département de Biologie, \\ Université de la Méditerranée, ${ }^{4} 13288$ Marseille Cedex 9, Sanofi Recherche, Unité de Microbiologie, Groupe Elf- \\ Aquitaine, 31676 Labège Cedex, ${ }^{3}$ Laboratoire de Microbiologie, Faculté des Sciences Pharmaceutiques et Biologiques, \\ Université René Descartes, 75270 Paris Cedex 6, ${ }^{5}$ and Laboratoire de Biochimie, Hôpital St-Vincent-de-Paul, 75674 \\ Paris Cedex 14, ${ }^{6}$ France, and School of Biomolecular and Biomedical Sciences, Faculty of Science and Technology, \\ Griffith University, Brisbane, Queensland 4111, Australia ${ }^{2}$
}

\begin{abstract}
A new thermophilic, xylanolytic, strictly anaerobic, rod-shaped bacterium, strain SEBR $7054^{\mathrm{T}}$, was isolated from an African oil-producing well. Based on the presence of an outer sheath (toga) and 16S rRNA sequence analysis data, this organism was identified as a member of the genus Thermotoga. Strain SEBR $7054^{\mathrm{T}}$ possessed lateral flagella, had a $\mathbf{G}+\mathrm{C}$ content of $50 \mathrm{~mol} \%$, produced traces of ethanol from glucose but no lactate, and grew optimally in the presence of 0 to $0.2 \% \mathrm{NaCl}$ at $70^{\circ} \mathrm{C}$. Its phenotypic and phylogenetic characteristics clearly differed from those reported for the five previously validly described Thermotoga species. Therefore, we propose that strain SEBR $7054^{\mathrm{T}}$ is a member of a new species of the genus Thermotoga, Thermotoga hypogea sp. nov. The type strain of $T$. hypogea is SEBR 7054 (= DSM 11164).
\end{abstract}

Members of the order Thermotogales are rod-shaped bacteria that have a characteristic outer sheathlike structure called a toga. This order includes the following five genera: Thermotoga $(18,22,23,34,44)$, Thermosipho $(19,37)$, Fervidobacterium $(1$, 20,32), Geotoga, and Petrotoga (9). It represents, along with the Aquificales, the deepest phylogenetic branch in the domain Bacteria (45). The genus Thermotoga includes all of the hyperthermophiles (optimum temperature for growth, around $80^{\circ} \mathrm{C}$ ) of the order Thermotogales $(18,21,22)$ and the thermophiles (optimum temperature for growth, 65 to $70^{\circ} \mathrm{C}$ ) recently isolated from oil fields $(23,34)$.

Stetter et al. (39) provided evidence of the presence of Thermotoga strains in oil fields. The isolation of Thermotoga elfii and Thermotoga subterranea from such ecosystems was reported soon thereafter $(23,34)$. In contrast to Thermotoga maritima and Thermotoga neapolitana, T. elfii and T. subterranea were not able to grow at temperatures above $75^{\circ} \mathrm{C}$ and reduced thiosulfate but not sulfur, which led to speculation that thiosulfate rather than sulfur may be an important electron acceptor in oil field ecosystems (34). The presence of thiosulfate is also thought to increase biocorrosion of oil field installations $(8,27)$. We therefore initiated intensive studies to isolate Thermotoga strains from oil field subsurface ecosystems that grow at temperatures above $80^{\circ} \mathrm{C}$ and use thiosulfate as an electron acceptor. Our studies have focused on xylanolytic extremophilic microorganisms since thermostable xylanases have a potential use in paper primary-pulp manufacturing (33). In this paper, we describe the first isolation from oil field water of a xylanolytic Thermotoga species able to grow at temperatures up to $90^{\circ} \mathrm{C}$. The phenotypic and phylogenetic characteristics of the new strain are consistent with its placement in a new species of the genus Thermotoga, Thermotoga hypogea sp. nov.

\footnotetext{
* Corresponding author. Mailing address: Laboratoire ORSTOM de Microbiologie des Anaérobies, Université de Provence, CESBESIL case 925, 163 Avenue de Luminy, 13288 Marseille Cedex 9, France. Phone: 33.4.91.82.85.76. Fax: 33.4.91.82.85.70. E-mail:ollivier @orstom.esil.univ-mrs.fr.
}

\section{MATERIALS AND METHODS}

Sample collection and sample source. Strain SEBR $7054^{\mathrm{T}}$ was isolated from an oil-producing well in Cameroon in central Africa. The in situ temperature was $66^{\circ} \mathrm{C}$, and the concentration of sodium chloride was $12 \mathrm{~g} /$ liter. A 1-liter sample was collected at the wellhead as described elsewhere (3), transported to our laboratory, and stored at $4^{\circ} \mathrm{C}$ until it was used.

Other strain. Thermotoga thermarum DSM 5069 was obtained from Deutsche Sammlung von Mikroorganismen und Zellkulturen GmbH.

Culture media. Enrichment was performed by using MB medium containing $1 \mathrm{~g}$ of $\mathrm{NH}_{4} \mathrm{Cl}, 0.3 \mathrm{~g}$ of $\mathrm{K}_{2} \mathrm{HPO}_{4}, 0.3 \mathrm{~g}$ of $\mathrm{KH}_{2} \mathrm{PO}_{4}, 0.5 \mathrm{~g}$ of $\mathrm{MgCl}_{2}, 0.1 \mathrm{~g}$ of $\mathrm{CaCl}_{2}$, $10 \mathrm{~g}$ of $\mathrm{NaCl}, 0.2 \mathrm{~g}$ of KCl, $0.5 \mathrm{~g}$ of cysteine-HCl, $2 \mathrm{~g}$ of yeast extract (Difco Laboratories, Detroit, Mich.), 2 g of bio-Trypticase (bioMérieux, Marcy l'Etoile, France), $10 \mathrm{~g}$ of xylan, $10 \mathrm{ml}$ of the trace mineral element solution of Balch et al. (2), $1 \mathrm{mg}$ of resazurin, and 1 liter of distilled water. The $\mathrm{pH}$ was adjusted to 8.0 with $10 \mathrm{M} \mathrm{KOH}$, and the medium was boiled under a stream of $\mathrm{O}_{2}$-free $\mathrm{N}_{2}$ gas and cooled to room temperature. Then 5 - and $20-\mathrm{ml}$ aliquots were dispensed into Hungate tubes and serum bottles, respectively, under a stream of $\mathrm{N}_{2}-\mathrm{CO}_{2}(80: 20$, vol:vol), and the vessels were autoclaved for $45 \mathrm{~min}$ at $110^{\circ} \mathrm{C}$. Prior to inoculation, $\mathrm{Na}_{2} \mathrm{~S} \cdot 9 \mathrm{H}_{2} \mathrm{O}, \mathrm{Na}_{2} \mathrm{CO}_{3}$, and thiosulfate were injected from sterile stock solutions to obtain final concentrations of $0.04 \%, 0.2 \%$, and $20 \mathrm{mM}$, respectively. For isolation, MBX medium (MB medium in which xylan was replaced by $20 \mathrm{mM}$ xylose) was used.

Enrichment and isolation. A 2-ml sample of well water was inoculated into 20 $\mathrm{ml}$ of medium, which was incubated at $70^{\circ} \mathrm{C}$ without agitation to initiate an enrichment culture. The culture was purified by repeated use of the Hungate roll tube method with MBX medium solidified with $4 \%$ Phytagel as described by Deming and Baross (11).

$\mathrm{pH}$, temperature, and $\mathrm{NaCl}$ concentration ranges for growth. The $\mathrm{pH}$, temperature, and $\mathrm{NaCl}$ concentration ranges for growth were determined by using MB medium containing $1 \mathrm{~g}$ of yeast extract per liter and $5 \mathrm{~g}$ of bio-Trypticase per liter but no xylan. The $\mathrm{pH}$ of the medium in Hungate tubes was adjusted by injecting $\mathrm{NaHCO}_{3}$ or $\mathrm{Na}_{2} \mathrm{CO}_{3}$ from $10 \%$ sterile anaerobic stock solutions. Mineral oil baths were used to obtain incubation temperatures of $>50^{\circ} \mathrm{C}$ : For studies of $\mathrm{NaCl}$ requirements, $\mathrm{NaCl}$ was weighed directly in the tubes before the medium was dispensed. The strain was subcultured at least once under the same experimental conditions before the growth rates were determined.

Substrate utilization tests. Substrates were tested at a final concentration of 20 $\mathrm{mM}$ in the absence or presence of sodium thiosulfate in $\mathrm{MB}$ medium which was modified to contain $1 \mathrm{~g}$ of yeast extract per liter and $1 \mathrm{~g}$ of bio-Trypticase per liter. T. thermarum was cultured in the same medium containing $3 \mathrm{~g}$ of $\mathrm{NaCl}$ per liter. To test for electron acceptors, sodium thiosulfate, sodium sulfate, and elemental sulfur (Prolabo, Paris, France) were added to the medium at final concentrations of $20 \mathrm{mM}, 20 \mathrm{mM}$, and $2 \%$ (wt/vol), respectively.

Light microscopy and electron microscopy. Light microscopy was performed as previously described (5). For electron microscopy, exponentially grown cells were negatively stained with $1 \%$ sodium phosphotungstic acid (pH 7.2). To prepare thin sections, exponentially grown cells were centrifuged, fixed for $1 \mathrm{~h}$ in $3 \%$ (wt/vol) glutaraldehyde in $\mathrm{HCl}$-cacodylate buffer ( $\mathrm{pH} \mathrm{6.0)}$ containing $0.7 \mathrm{M}$ sucrose, and postfixed overnight in $1 \%$ (wt/vol) osmium tetraoxide in $0.75 \mathrm{M}$ 
sucrose. Then the cells were washed, embedded in $2 \%$ agarose, and stained with $4 \%$ uranyl acetate. The agar was cut into small cubes, dehydrated in acetone, and embedded in Araldite. Thin sections were stained with 5\% uranyl acetate for 20 min and with $2 \%$ lead citrate for $10 \mathrm{~min}$. Micrographs were taken with a Hitachi model $\mathrm{H} 600$ electron microscope at an accelerating voltage of $75 \mathrm{kV}$.

Analytical techniques. Unless otherwise indicated, duplicate culture tubes were used throughout the analytical studies. Growth was measured by inserting tubes directly into a model UV-160A spectrophotometer (Shimadzu Corp., Kyoto, Japan) and measuring the optical density at $580 \mathrm{~nm}$. Sulfide was determined photometrically as collodial CuS by using the method of Cord- Ruwisch (7). $\mathrm{H}_{2}, \mathrm{CO}_{2}$, sugars, alcohols, and volatile and nonvolatile fatty acids were measured as described previously $(13,14), \mathrm{CO}_{2}$ was measured in $\mathrm{MB}$ medium that lacked xylan but contained $20 \mathrm{mM}$ glucose. In this medium, $\mathrm{N}_{2}-\mathrm{CO}_{2}$ and bicarbonate buffer were replaced by $\mathrm{N}_{2}$ and phosphate buffer, respectively. LAlanine was determined enzymatically with an L-alanine dehydrogenase kit (catalog no. A-7653; Sigma). Cell-free supernatant was deproteinized with an equal volume of $1 \mathrm{M}$ sodium perchlorate, and the mixture was centrifuged and neutralized with $\mathrm{KHCO}_{3}$. Fifty microliters of the sample was mixed with $200 \mu \mathrm{l}$ of Tris $\mathrm{HCl}(\mathrm{pH} \mathrm{10.0)}$. Then L-alanine was determined by using the manufacturer's instructions. Gram staining was performed with a Sigma kit.

Enzyme assays. For xylanolytic activity measurements, cells were harvested in the late exponential or early stationary phase. Cells were collected by centrifugation at 13,000 rpm (Biofuge 13; Heraeus, Les Ulis, France) for $10 \mathrm{~min}$ at $4^{\circ} \mathrm{C}$. Reducing sugars were quantified with dinitrosalicylic acid (31). Xylanolytic activity was assayed in the supernatant and in resuspended cells by measuring the release of reducing sugars from xylan. Each assay mixture consisted of $0.5 \%$ (wt/vol) xylan supplemented with $100 \mathrm{mM}$ acetate buffer ( $\mathrm{pH}$ 6.5) and enough enzyme so that the final volume was $0.2 \mathrm{ml}$. The reaction mixture was incubated for $30 \mathrm{~min}$ at $70^{\circ} \mathrm{C}$. The assay was terminated by adding dinitrosalicylic acid, and the xylose released from xylan was measured at $540 \mathrm{~nm}$. Controls with substrate and no enzyme were included. One unit of xylanase activity was defined as the amount of enzyme required to liberate $1 \mu \mathrm{mol}$ of xylose per min at $70^{\circ} \mathrm{C}$.

Determination of $\mathbf{G}+\mathrm{C}$ content. The $\mathrm{G}+\mathrm{C}$ content of DNA was determined at the DSM-Deutsche Sammlung von Mikroorganismen und Zellkulturen GmbH Braunschweig, Germany. DNA was isolated and purified by chromatography on hydroxyapatite, and its $\mathrm{G}+\mathrm{C}$ content was determined by using high-performance liquid chromatography as described by Mesbah et al. (30). Nonmethylated lambda DNA (Sigma) was used as the standard.

$16 S$ rRNA sequence studies. The methods used for purification and extraction of DNA and amplification and sequencing of the 16S rRNA gene have been described previously $(1,26,38)$. The $16 \mathrm{~S}$ rRNA gene sequence was manually aligned with reference sequences of various members of the domain Bacteria by using the editor ae 2 (28). Reference sequences were obtained from the Ribosomal Database Project (28) and the EMBL and GenBank databases. Positions of sequence and alignment uncertainty were omitted from the analysis. A phylogenetic analysis was performed by using the various programs implemented as part of the PHYLIP package (15), as described below. Pairwise evolutionary distances based on 1,121 unambiguous nucleotides were computed by the method of Jukes and Cantor (24), and dendrograms were constructed from these distances by the neighbor-joining method.

Nucleotide sequence accession number. The $16 \mathrm{~S}$ rRNA sequence of strain SEBR $7054^{\mathrm{T}}$ has been deposited in the GenBank database under accession no. U89768.

\section{RESULTS}

Enrichment and isolation. Enrichment cultures were positive after incubation at $70^{\circ} \mathrm{C}$ for 3 days, and $\mathrm{H}_{2} \mathrm{~S}$ was detected from thiosulfate reduction. Microscopic examination revealed the presence of rod-shaped bacteria with an outer sheathlike structure characteristic of members of the order Thermotogales. Colonies that were $1 \mathrm{~mm}$ in diameter developed in Phytagel roll tubes after 7 days of growth at $70^{\circ} \mathrm{C}$. Single colonies were picked, and serial dilution in Phytagel roll tubes was repeated at least twice before the culture was considered pure. Several axenic cultures containing cells with the typical outer polar sheathlike structures characteristic of members of the Thermotogales were obtained. One strain, strain SEBR $7054^{\mathrm{T}}$, was used for further characterization.

Morphology. Strain SEBR $7054^{\mathrm{T}}$ was a rod-shaped bacterium. The cells were 0.5 to 1 by 2 to $3 \mu \mathrm{m}$ and occurred singly or in pairs (Fig. 1a). No motility was observed by microscopy, but the cells possessed laterally inserted flagella (Fig. 1b) and were surrounded by a characteristic toga, a sheathlike structure that ballooned over the cell ends (Fig. 1c). Electron microscopy of thin sections of strain SEBR $7054^{\mathrm{T}}$ revealed a typical toga cell wall ultrastructure with a spongy periplasm layer (Fig. 1d). The cells stained gram negative.

Optimum growth conditions. Strain SEBR $7054^{\mathrm{T}}$ did not grow in oxidized medium (oxidation was indicated by the pink color of the resazurin). It grew at temperatures ranging from 56 to $90^{\circ} \mathrm{C}$, and optimum growth occurred at $70^{\circ} \mathrm{C}$ at $\mathrm{pH} 7.0$ (Fig. 2a). Growth occurred at initial $\mathrm{pH}$ values between 6.1 and 9.1 at $70^{\circ} \mathrm{C}$, and the optimum $\mathrm{pH}$ was 7.3 to 7.4 . At the end of growth, the $\mathrm{pH}$ had decreased by 0.2 to $0.3 \mathrm{U}$. The isolate grew in $\mathrm{MB}$ medium in the presence of $\mathrm{NaCl}$ concentrations ranging from 0 to $1.5 \%$, and the optimum $\mathrm{NaCl}$ concentration was between 0 and $0.2 \%$ at $\mathrm{pH} 7.0$ and $70^{\circ} \mathrm{C}$ (Fig. 2b). T. thermarum grew in the same medium containing $0.3 \% \mathrm{NaCl}$ but did not grow in the presence of $1 \% \mathrm{NaCl}$.

Substrates used for growth. Yeast extract or bio-Trypticase was required for growth on carbohydrates, and these compounds were fermented by strain SEBR $7054^{\mathrm{T}}$. Yeast extract could not be replaced by Casamino Acids ( $1 \mathrm{~g} /$ liter), vitamins (42), or a mixture of Casamino Acids and vitamins. Strain SEBR $7054^{T}$ grew on the following substrates (at a concentration of $20 \mathrm{mM}$ unless indicated otherwise): D-fructose, D-galactose, D-glucose, DL-lactose, DL-maltose, D-mannose, D-sucrose, D-xylose, and xylan (10 g/liter). It could not utilize Darabinose, D-ribose, L-sorbose, L-xylose, and fatty acids (acetate, butyrate, lactate, and propionate). Acetate, L-alanine, $\mathrm{CO}_{2}, \mathrm{H}_{2}$, and traces of ethanol were produced during xylose fermentation irrespective of the presence of thiosulfate (Table 1 ); a similar profile of metabolites was produced by glucose fermentation. In all cases, about $1 \mathrm{~mol}$ of $\mathrm{CO}_{2}$ was produced per mol of acetate produced. The level of carbon recovery ranged from 50 to $80 \%$. Low carbon recovery values were obtained with other thermophilic anaerobes (43). In addition, in the case of $T$. maritima (18) unidentified products of sugar metabolism were detected by thin-layer chromatography. $T$. thermarum grew on sucrose and xylose, but not on D-fructose, D-galactose, DL-lactose, D-mannose, D-arabinose, and L-sorbose. $T$. thermarum also produced traces of ethanol during glucose fermentation.

Effect of added electron acceptors. Strain SEBR $7054^{\mathrm{T}}$ reduced thiosulfate but not sulfate or sulfur to sulfide. The presence of thiosulfate increased biomass and improved the utilization of glucose but not the utilization of xylose (Table 1). In addition, it altered the concentration of metabolites during glucose and xylose oxidation, indicating that thiosulfate modified the metabolic pathway of strain SEBR $7054^{\mathrm{T}}$. The changes observed were as follows: (i) thiosulfate was reduced to sulfide with a concomitant decrease in $\mathbf{H}_{2}$ to barely detectable levels; and (ii) the ratio of acetate produced to sugar consumed increased in the presence of thiosulfate, whereas the ratio of L-alanine produced to sugar consumed decreased (Table 1). T. thermarum also reduced thiosulfate to sulfide.

Sensitivity to rifampin. Strain SEBR $7054^{\mathrm{T}}$ grew in the presence of rifampin (final concentration, $100 \mu \mathrm{g} / \mathrm{ml}$ ).

Xylanase production in batch culture. Strain SEBR $7054^{\mathrm{T}}$ grew with xylan as an energy source. We found that at the end of growth, xylanase activity was present with xylan as the substrate and cell-free culture medium or resuspended cells as the enzyme source; the xylanase activities obtained with cell-free culture medium and resuspended cells were estimated to be 93 and $81 \mathrm{U} /$ liter, respectively.

$\mathbf{G}+\mathbf{C}$ content. The $\mathrm{G}+\mathrm{C}$ content of isolate SEBR $7054^{\mathrm{T}}$ was $50 \mathrm{~mol} \%$.

16S rRNA sequence analysis. Using 12 primers, we determined 1,497 bases of the $16 \mathrm{~S}$ rRNA gene sequence of strain SEBR $7054^{\mathrm{T}}$. A phylogenetic analysis revealed that strain SEBR $7054^{\mathrm{T}}$ was a member of the order Thermotogales and 

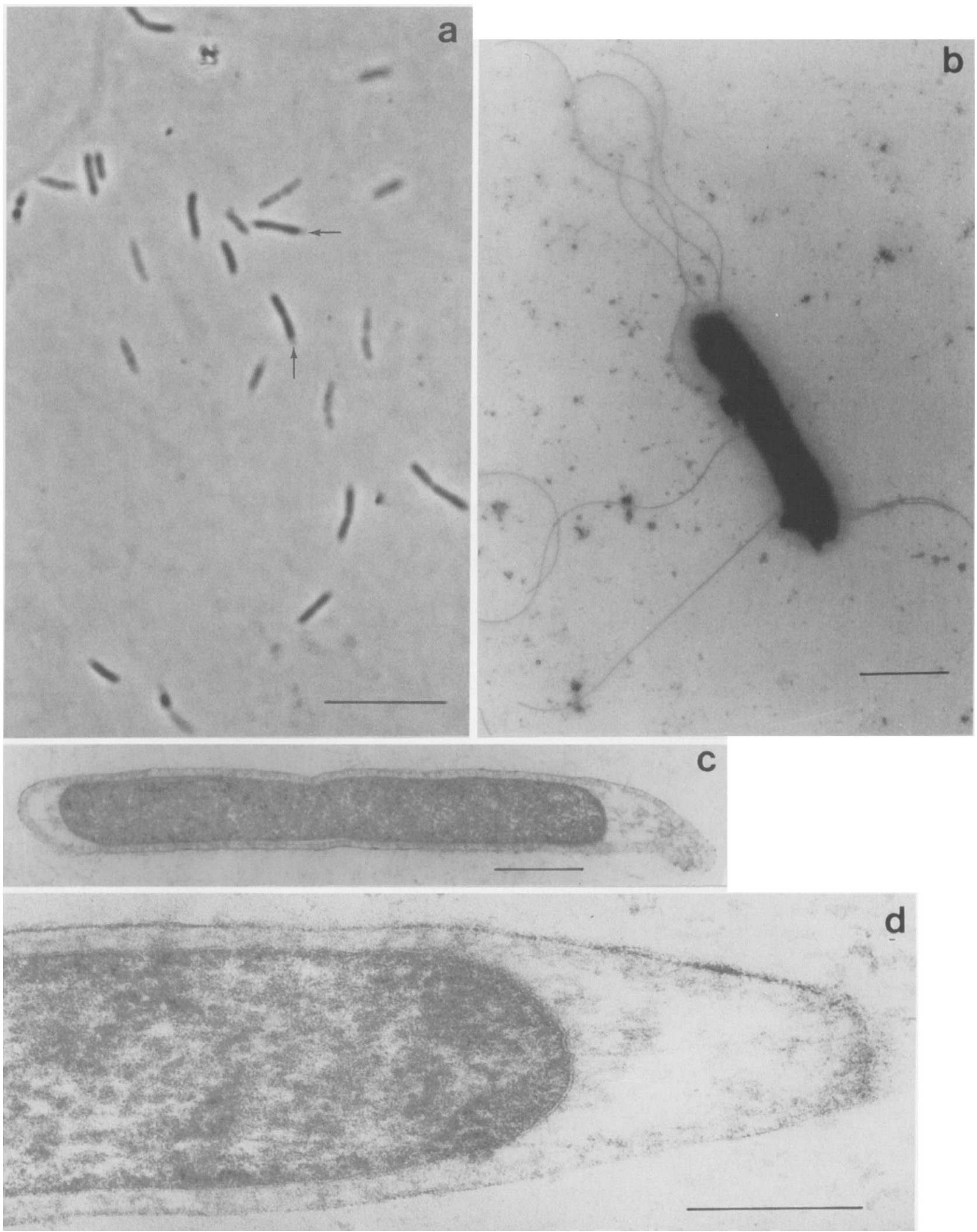

FIG. 1. (a) Phase-contrast micrograph of strain SEBR $7054^{\mathrm{T}}$, showing the toga (arrows), a characteristic structure of Thermotoga species. Bar $=10 \mu \mathrm{m}$. (b) Electron micrograph of a negatively stained culture of strain SEBR $7054^{\mathrm{T}}$, showing laterally inserted flagella. Bar $=2 \mu \mathrm{m}$. (c) Electron micrograph of a thin section of strain SEBR $7054^{\mathrm{T}}$, showing the typical outer sheathlike structure (toga) of the genus Thermotoga. Bar $=0.5 \mu \mathrm{m}$. (d) Electron micrograph of a thin section of strain SEBR $7054^{\mathrm{T}}$, showing the thin electron-dense layer of the cell wall, presumably a peptidoglycan layer covering a spongy periplasmic layer that expands at both ends. Bar $=$ $0.2 \mu \mathrm{m}$. 

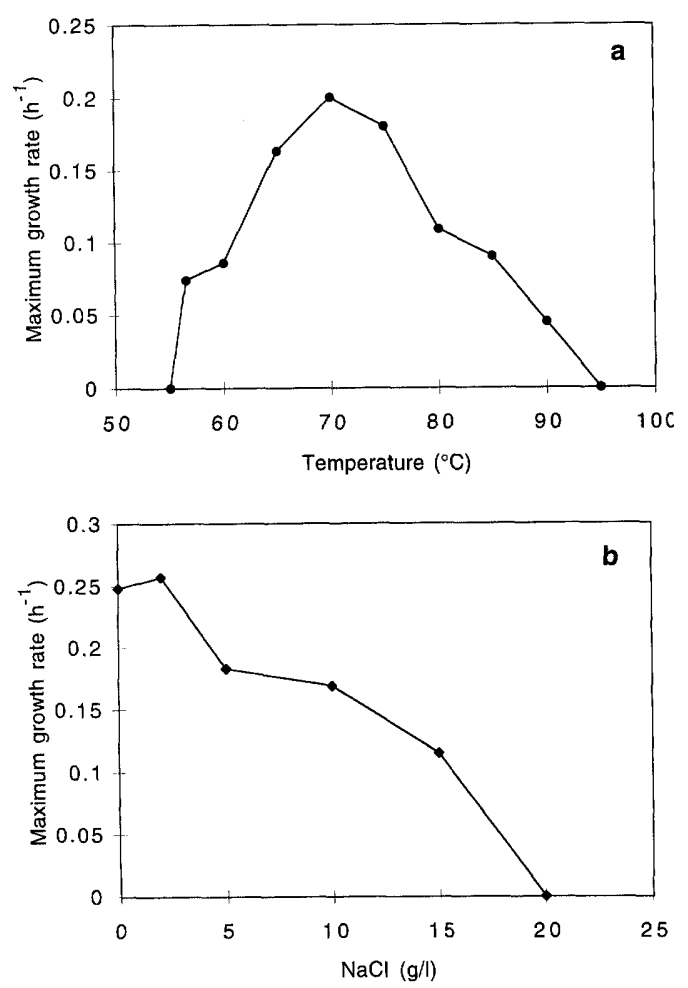

FIG. 2. Effect of temperature (a) and $\mathrm{NaCl}$ (b) on the growth of strain SEBR $7054^{\mathrm{T}}$.

that its closest relatives were T. elfii (level of similarity, 94\%), T. maritima (level of similarity, $93.7 \%$ ), and T. thermarum (level of similarity, 95.9\%). Figure 3 is a dendrogram generated by the neighbor-joining method (15) from the JukesCantor evolutionary similarity matrix (24).

\section{DISCUSSION}

Hyperthermophilic members of the Archaea $(25,39)$ and thermophilic members of the Bacteria $(13,23,25,34,39)$ inhabit oil field ecosystems, suggesting that these environments are suitable ecological niches from which new thermophilic and hyperthermophilic anaerobes can be isolated. Studies of these organisms may be useful in the development of microbeenhanced oil recovery processes $(4,29)$. In addition, members of the order Thermotogales and Thermoanaerobacter species, which have the ability to reduce thiosulfate during growth on carbohydrates $(14,36)$, may be involved in biocorrosion of oil field facilities $(8,10,12,16,27)$.

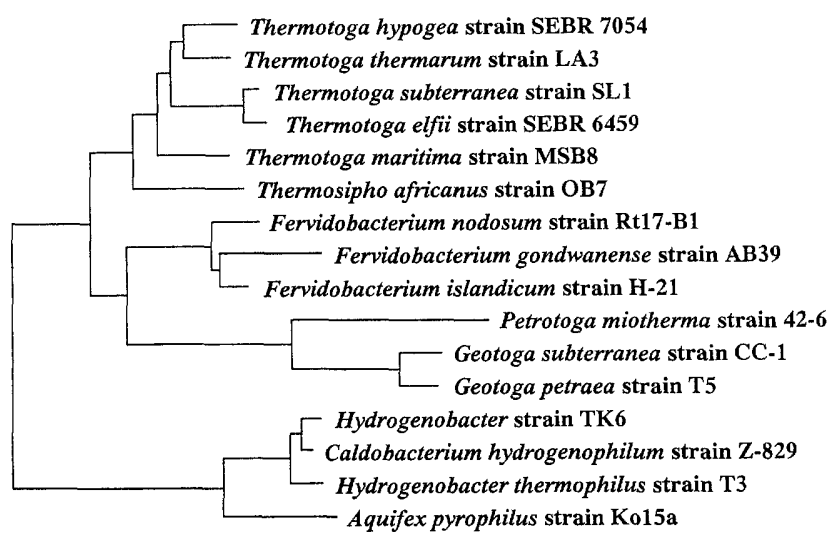

.10

FIG. 3. Dendrogram showing the position of strain SEBR $7054^{\mathrm{T}}$ among the members of the order Thermotogales and related bacteria. Bar = evolutionary distance of 0.10 .

Strain SEBR $7054^{\mathrm{T}}$ is an anaerobic, rod-shaped thermophile with an outer sheathlike structure (toga) similar to that described for the members of the genera Thermosipho, Geotoga, Petrotoga, and Thermotoga. However, the outer sheathlike structure is marginally wider than the cell, and therefore strain SEBR $7054^{\mathrm{T}}$ is not a member of Fervidobacterium species, which possess a toga that is six to eight times broader than the cell $(1,20,32)$. Strain SEBR $7054^{\mathrm{T}}$ also differs from Thermosipho species, whose cells resemble sausages strung together within a sheathlike structure (19). On the basis of its optimum temperature for growth and sodium chloride requirements, isolate SEBR $7054^{\mathrm{T}}$ clearly differs from Petrotoga and Geotoga species (9).

The phylogenetic analysis of $16 \mathrm{~S}$ rRNAs indicated that strain SEBR $7054^{\mathrm{T}}$ is a member of the genus Thermotoga. However, the sequence of the 16S rRNA gene of strain SEBR $7054^{\mathrm{T}}$ differs enough (average difference, 5\%) from the sequences of the five previously described Thermotoga species to warrant inclusion of this organism in the genus as a new species. However, as recently proposed by Vandamme et al. (41), a polyphasic approach in which phylogenetic, genomic, and phenotypic traits are examined should be used to define new species. Strain SEBR $7054^{\mathrm{T}}$ differs phenotypically from the five previously described Thermotoga species in numerous ways (Table 2). In particular, it differs from its closest phylogenetic relative (level of similarity, $95.9 \%$ ), $T$. thermarum, by having (i) a higher DNA G+C content (50 instead of $40 \mathrm{~mol} \%$ ), (ii) a different temperature range for growth, and (iii) a different substrate range for growth (strain SEBR $7054^{\mathrm{T}}$ uses D-fructose,

TABLE 1. Fermentation of xylose and glucose in the presence or absence of thiosulfate by strain SEBR $7054^{\mathrm{T}}$

\begin{tabular}{|c|c|c|c|c|c|c|c|c|c|}
\hline \multirow{2}{*}{ Culture conditions ${ }^{a}$} & \multirow{2}{*}{$\begin{array}{c}\text { Amt of } \\
\text { substrate } \\
\text { utilized }(\mathrm{mM})\end{array}$} & \multirow{2}{*}{$\begin{array}{l}\text { Maximum } \\
\text { optical density } \\
\text { at } 580 \mathrm{~nm}\end{array}$} & \multicolumn{5}{|c|}{ Amt of end products formed (mM) } & \multirow{2}{*}{$\begin{array}{l}\text { Ratio of acetate } \\
\text { produced to } \\
\text { sugar consumed }\end{array}$} & \multirow{2}{*}{$\begin{array}{l}\text { Ratio of L- } \\
\text { alanine } \\
\text { produced to } \\
\text { sugar consumed }\end{array}$} \\
\hline & & & $\mathrm{H}_{2}^{b}$ & Ethanol & $\mathrm{H}_{2} \mathrm{~S}$ & Acetate & L-Alanine & & \\
\hline Xylose & 12.9 & 0.40 & 19.0 & 1.0 & 0.2 & 8.9 & 2.4 & 0.69 & 0.18 \\
\hline Xylose + thiosulfate & 12.0 & 0.66 & 1.8 & 1.0 & 7.5 & 13.7 & 1.3 & 1.14 & 0.10 \\
\hline Glucose & 7.0 & 0.35 & 9.4 & 1.0 & 0.2 & 5.0 & 1.7 & 0.71 & 0.24 \\
\hline Glucose + thiosulfate & 13.0 & 0.92 & 0.9 & 1.6 & 15.1 & 19.8 & 1.0 & 1.52 & 0.07 \\
\hline
\end{tabular}

${ }^{a}$ Sodium thiosulfate was added at a final concentration of $20 \mathrm{mM}$. The results shown are the results after $143 \mathrm{~h}$ of growth at $70^{\circ} \mathrm{C}$. Uninoculated controls did not exhibit $\mathrm{H}_{2} \mathrm{~S}$ production after 1 week of incubation at $70^{\circ} \mathrm{C}$ in the presence or absence of thiosulfate.

${ }^{b}$ Amount of $\mathrm{H}_{2}$ produced in millimolar equivalents. 

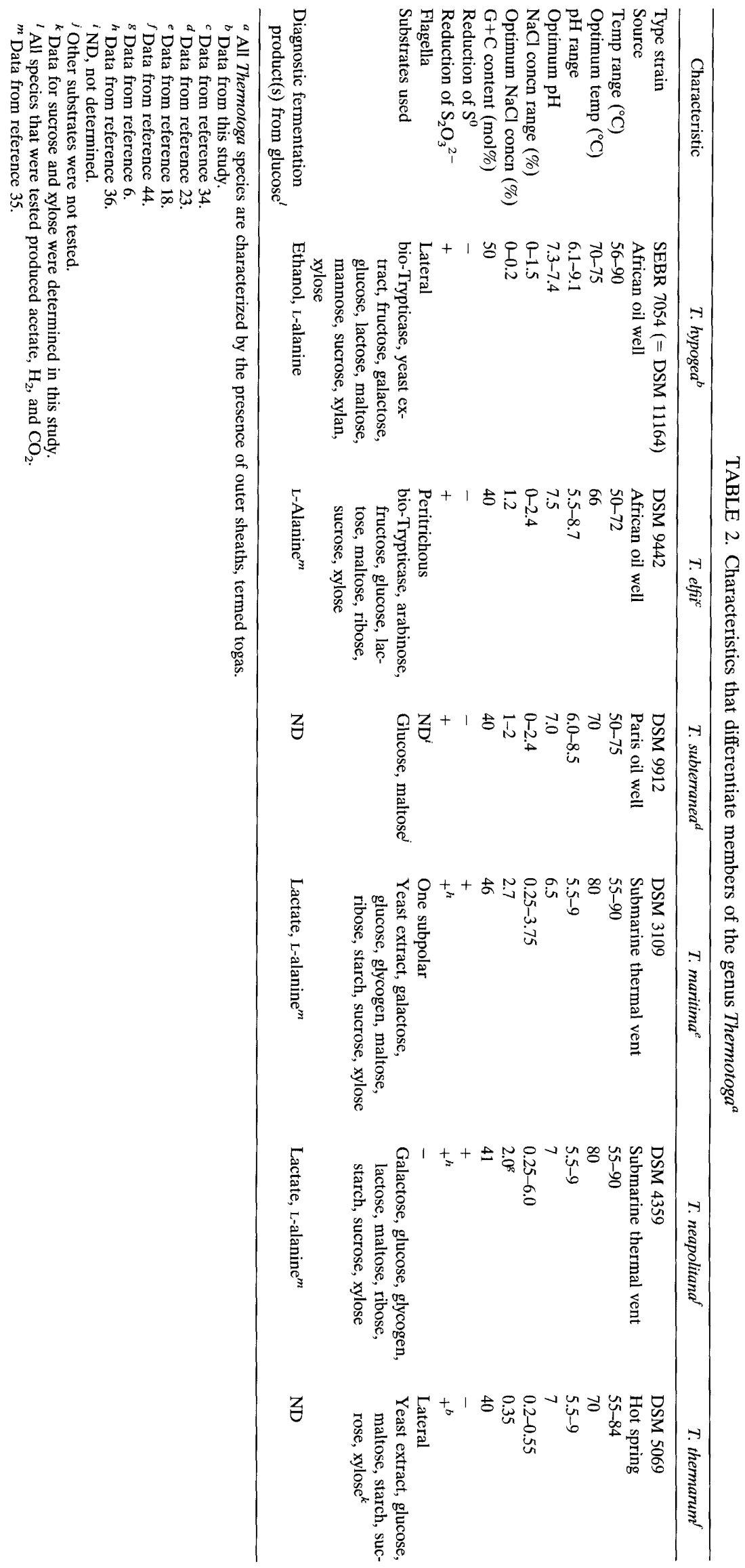
DL-lactose, D-mannose, and D-galactose, whereas T. thermarum does not) (Table 2).

The ability of Thermotoga sp. strain SEBR $7054^{\mathrm{T}}$ to grow optimally at $70^{\circ} \mathrm{C}$ reflects its habitat temperature $\left(66^{\circ} \mathrm{C}\right)$, but its ability to grow at temperatures up to $90^{\circ} \mathrm{C}$ is surprising. It is possible that oil fields are physicochemically heterogeneous and that Thermotoga sp. strain SEBR $7054^{\mathrm{T}}$ may grow in hot spots within oil fields.

On the basis of ecological studies (44), Thermotoga isolates were separated into two different groups, with $T$. maritima and $T$. neapolitana representing the marine isolates and $T$. thermarum representing terrestrial isolates that are able to grow at low levels of salinity. Strain SEBR $7054^{\mathrm{T}}$, together with recent isolates from oil field water ( $T$. elfii and $T$. subterranea), represents a third ecological group originating from subsurface ecosystems and adapted to levels of salinity intermediate between those of marine species and those of terrestrial species. In this respect, microbiological studies of subsurface ecosystems improved our knowledge of the ecological distribution of the Thermotogales.

Thermotoga sp. strain SEBR $7054^{\mathrm{T}}$ was similar to $T$. elfii and $T$. subterranea in its ability to reduce thiosulfate but not sulfur to hydrogen sulfide. This adds weight to the hypothesis that thiosulfate may be a more important electron acceptor than sulfur in oil field ecosystems (34). However, this is not an exclusive trait of all oil fields since Thermotoga sp. strain SEBR 2665 , an isolate from the Paris Basin oil field, can use both thiosulfate and sulfur as electron acceptors (36).

Our results provide evidence that the use of thiosulfate by strain SEBR $7054^{\mathrm{T}}$ causes a shift in the flow of electrons, favoring $\mathrm{H}_{2} \mathrm{~S}$ production. This channels the electrons partially away from L-alanine to acetate, thereby increasing the acetate concentration. Such a shift in metabolism in the presence of thiosulfate has been reported previously for Thermoanaerobacter brockii grown on glucose or xylose (14). Under these conditions, acetate production increased and there was a concomitant decrease in lactate and ethanol production (14). It was therefore hypothesized that thiosulfate reduction might be an important feature in thermal ecosystems with regard to organic matter oxidation. It is noteworthy that Thermoanaerobacter and Thermotoga strains are common inhabitants of oil well water $(13,17,23,39)$. Therefore, the presence of thiosulfate could drastically change the fate of organic matter available in such ecosystems.

The production of L-alanine as an end product of glucose fermentation has been reported for Thermotoga species, and it has been hypothesized that this is an ancestral metabolism (35). We show for the first time that L-alanine is also produced from xylose fermentation. In addition, Thermotoga sp. strain SEBR $7054^{\mathrm{T}}$ and $T$. thermarum produce ethanol as an end product of glucose fermentation, and this is the first report of this trait in members of Thermotoga species. The physiological data provided in this report may be useful for initiating evolutionary studies of enzymes involved in the production of L-alanine and ethanol dehydrogenases. Thermotoga sp. strain SEBR $7054^{\mathrm{T}} ;$ T. maritima, and T. neapolitana have the highest growth temperature $\left(90^{\circ} \mathrm{C}\right)$ in the domain Bacteria. We provide evidence of xylanolytic activity in Thermotoga sp. strain SEBR $7054^{\mathrm{T}}$; therefore, it should be useful to compare the thermostabilities of xylanases in our isolate, T. maritima, and T. neapolitana since thermostability is a desirable property for enzymes in many industrial applications $(33,40)$.

The $\mathrm{G}+\mathrm{C}$ content of Thermotoga sp. strain SEBR $7054^{\mathrm{T}}$ (50 mol\%) differs substantially from the values reported for the five previously described Thermotoga species (40 to $46 \mathrm{~mol} \%$ ). Isolate SEBR $7054^{\mathrm{T}}$ is a xylanolytic anaerobe that is suffi- ciently phenotypically and phylogenetically distinct from the five previously described Thermotoga species to be proposed as a member of a new species of the genus Thermotoga, T. hypogea $\mathrm{sp}$. nov. In addition, in this paper we provide further phenotypic characterization of $T$. thermarum with regard to its substrate range for growth and provide evidence that this organism is able to reduce thiosulfate to sulfide, which indicates that this function is quite widespread in the Thermotogales, as previously suggested (36).

Description of Thermotoga hypogea sp. nov. Thermotoga hypogea (hy. po.ge'a. Gr. pron. hypos, under; Gr. n. ge, earth; L. fem. adj. hypogea, under the earth, referring to the site of isolation). Round colonies (diameter, $1 \mathrm{~mm}$ ) are present after 7 days of incubation at $70^{\circ} \mathrm{C}$. Cells are rods $(0.5$ to 1 by 2 to 3 $\mu \mathrm{m})$, and each cell has an outer sheathlike structure (toga). The cells stain gram negative, occur singly or in pairs, and possess laterally inserted flagella. Chemoorganotrophic and obligately anaerobic member of the domain Bacteria. The optimum temperature for growth is $70^{\circ} \mathrm{C}$ at $\mathrm{pH} 7.0$; the temperature range is 56 to $90^{\circ} \mathrm{C}$. The optimum $\mathrm{pH}$ is 7.3 to 7.4 at $70^{\circ} \mathrm{C}$; growth occurs between $\mathrm{pH} 6.1$ and $\mathrm{pH} 9.1$. The optimum $\mathrm{NaCl}$ concentration for growth is between 0 and $0.2 \%$ at $70^{\circ} \mathrm{C}$ and $\mathrm{pH} 7.0$; growth occurs in the presence of $\mathrm{NaCl}$ concentrations ranging from 0 and $1.5 \%$. Uses D-glucose, DL-fructose, D-galactose, DL-lactose, DL-maltose, D-mannose, D-sucrose, D-xylose, and xylan but not D-arabinose, D-ribose, L-sorbose, Lxylose, acetate, butyrate, lactate, or propionate. Ferments yeast extract and bio-Trypticase. Requires yeast extract or bio-Trypticase for growth on carbohydrates. Yeast extract cannot be replaced by Casamino Acids, a vitamin solution, or a mixture of Casamino Acids and vitamins. The end products of glucose and xylose fermentation are acetate, $\mathrm{CO}_{2}, \mathrm{H}_{2}$, L-alanine, and traces of ethanol. Uses thiosulfate as an electron acceptor during glucose fermentation, and under these conditions the biomass is greater than the biomass obtained with no added electron acceptor. $\mathrm{H}_{2} \mathrm{~S}$ is produced from thiosulfate reduction. Elemental sulfur cannot be used as an electron acceptor, and growth is not inhibited by elemental sulfur. The $\mathrm{G}+\mathrm{C}$ content of the DNA is $50 \mathrm{~mol} \%$ (as determined by high-performance liquid chromatography). Isolated from an oil-producing well. The type strain is SEBR 7054 (= DSM 11164).

\section{ACKNOWLEDGMENTS}

The financial assistance provided to B.K.C.P. by the Australian Research Council is gratefully acknowledged.

We thank J. L. Crolet for suggesting the species name, P. A. Roger for revising the manuscript, and J. L. Cayol for helpful discussions.

\section{REFERENCES}

1. Andrews, K. T., and B. K. C. Patel. 1996. Fervidobacterium gondwanense sp. nov., a new thermophilic anaerobic bacterium isolated from nonvolcanically heated geothermal waters of the Great Artesian Basin of Australia. Int. J. Syst. Bacteriol. 46:265-269.

2. Balch, W. E., G. E. Fox, R. J. Magrum, and R. S. Wolfe. 1979. Methanogens: reevaluation of a unique biological group. Microbiol. Rev. 43:260-296.

3. Bernard, F. P., J. Connan, and M. Magot. 1992. Indigenous microorganisms in connate water of many oil fields: a new tool in exploration and production techniques, p. 1-10. In Proceedings of the 67th Annual Technical Conference and Exhibition of the Society of Petroleum Engineers. Society of Petroleum Engineers, Richardson, Tex.

4. Bhupathiraju, V. K., and M. J. McInerney. 1993. Pretest studies for a microbially enhanced oil recovery field pilot in a hypersaline oil reservoir. Geomicrobiol. J. 11:19-34.

5. Cayol, J.-L., B. Ollivier, A. Lawson Anani Soh, M.-L. Fardeau, E. Ageron, P. A. D. Grimont, G. Prensier, J. Guezennec, M. Magot, and J.-L. Garcia. 1994. Haloincola saccharolytica subsp. senegalensis subsp. nov., isolated from the sediments of a hypersaline lake, and emended description of Haloincola saccharolytica. Int. J. Syst. Bacteriol. 44:805-811.

6. Childers, S. E., M. Vargas, and K. M. Noll. 1992. Improved methods for cultivation of the extremely thermophilic bacterium Thermotoga neapolitana. 
Appl. Environ. Microbiol. 58:3949-3953.

7. Cord-Ruwisch, R. 1985. A quick method for the determination of dissolved and precipitated sulfides in cultures of sulfate-reducing bacteria. J. Microbiol. Methods 4:33-36.

8. Crolet, J. L., S. Daumas, and M. Magot. 1993. pH regulation by sulfatereducing bacteria, p. 1-18. In Corrosion 93. National Association of Corrosion Engineers, Houston, Tex.

9. Davey, M. E., W. A. Wood, R. Key, K. Nakamura, and D. A. Stahl. 1993. Isolation of three species of Geotoga and Petrotoga: two new genera, representing a new lineage in the bacterial line of descent distantly related to the "Thermotogales." Syst. Appl. Microbiol. 16:191-200.

10. De Araujo-Jorge, T. C., C. M. L. Melo Coutinho, and L. E. Vargas De Aguiar. 1992. Sulphate-reducing bacteria associated with biocorrosion: a review. Mem. Inst. Oswaldo Cruz Rio de J. 87:329-337.

11. Deming, J. W., and J. A. Baross. 1986. Solid medium for culturing black smoker bacteria at temperature to $120^{\circ} \mathrm{C}$. Appl. Environ. Microbiol. 51:238 243.

12. Dzierzewicz, Z., B. Cwalina, L. Weglarz, and S. Glab. 1992. Isolation and evaluation of corrosive aggressivity of wild strains of sulphate-reducing bacteria. Acta Microbiol. Pol. 41:211-221.

13. Fardeau, M.-L., J.-L. Cayol, M. Magot, and B. Ollivier. $1993 . \mathrm{H}_{2}$ oxidation in the presence of thiosulfate, by a Thermoanaerobacter strain isolated from an oil-producing well. FEMS Microbiol. Lett. 113:327-332.

14. Fardeau, M.-L., C. Faudon, J.-L. Cayol, M. Magot, B. K. C. Patel, and B Ollivier. 1996. Effect of thiosulfate as electron acceptor on glucose and xylose oxidation by Thermoanaerobacter finnii and a Thermoanaerobacter $\mathrm{sp}$. isolated from oil field water. Res. Microbiol. 147:159-165.

15. Felsentein, J. 1993. PHYLIP (phylogenetic inference package), version 3.51c. Department of Genetics, University of Washington, Seattle.

16. Ferris, F. G., T. R. Jack, and B. J. Bramhill. 1992. Corrosion products associated with attached bacteria at an oil field water injection plant. Can. J. Microbiol, 38:1320-1324.

17. Grassia, G. S., K. M. McLean, P. Glénat, J. Bauld, and A. J. Sheehy. 1996 A systematic survey for thermophilic fermentative bacteria and archaea in high temperature petroleum reservoirs. FEMS Microbiol. Ecol. 21:47-58.

18. Huber, R., T. A. Langworthy, H. König, M. Thomm, C. R. Woese, U. W. Sleytr, and K. O. Stetter. 1986. Thermotoga maritima $\mathrm{sp}$. nov. represents a new genus of unique extremely thermophilic eubacteria growing up to $90^{\circ} \mathrm{C}$ Arch. Microbiol. 144:324-333.

19. Huber, R., C. R. Woese, T. A. Langworthy, H. Fricke, and K. O. Stetter. 1989 Thermosipho africanus gen. nov. represents a new genus of thermophilic eubacteria within the "Thermotogales". Syst. Appl. Microbiol. 12:32-37.

20. Huber, R., C. R. Woese, T. A. Langworthy, J. K. Kristjansson, and K. O. Stetter. 1990. Fervidobacterium islandicum sp. nov., a new extremely thermophilic eubacterium belonging to the "Thermotogales." Arch. Microbiol. 154:105-111.

21. Huser, B. A., B. K. C. Patel, H. W. Morgan, and R. M. Daniel. 1986. Isolation and characterization of a novel extremely thermophilic, anaerobic chemoorganotrophic eubacterium. FEMS Microbiol. Lett. 37:121-127.

22. Jannasch, H. W., R. Huber, S. Belkin, and K. O. Stetter. 1988. Themotoga neapolitana sp. nov. of the extremely thermophilic, eubacterial genus Thermotoga. Arch. Microbiol. 150:103-104.

23. Jeanthon, C., A.-L. Reysenbach, S. L'Haridon, A. Gambacorta, N. R. Pace, P. Glénat, and D. Prieur. 1995. Thermotoga subterranea sp. nov., a new thermophilic bacterium isolated from a continental oil reservoir. Arch. Microbiol. 164:91-97.

24. Jukes, T. H., and C. R. Cantor. 1969. Evolution of protein molecules, p. 21-132. In H. N. Munro (ed.), Mammalian protein metabolism. Academic Press, New York, N.Y.

25. L'Haridon, S., A.-L. Reysenbach, P. Glénat, D. Prieur, and C. Jeanthon. 1995. Hot subterranean biosphere in a continental oil reservoir. Nature 377:223-224.

26. Love, C. A., B. K. C. Patel, P. D. Nichols, and E. Stackebrandt. 1993. Desulfotomaculum australicum sp. nov., a thermophilic sulfate-reducing bac- terium isolated from the Great Artesian Basin of Australia. Syst. Appl. Microbiol. 16:244-251.

27. Magot, M., L. Carreau, J.-L. Cayol, B. Ollivier, and J.-L. Crolet. 1994 Sulphide-producing, not sulphate-reducing anaerobic bacteria presumptively involved in bacterial corrosion, p. 293. In C. A. C. Sequeira (ed.), Proceedings of the 3rd European Federation of Corrosion Workshop on Microbial Corrosion. The Institute of Materials, London, United Kingdom.

28. Maidak, B. L., G. J. Olsen, N. Larsen, R. Overbeek, M. J. McCaughey, and C. R. Woese. 1996. The Ribosomal Database Project (RDP). Nucleic Acids Res. 24:82-85.

29. McInerney, M. J., and D. W. S. Westlake. 1990. Microbially enhanced oil recovery, p. 409-455. In H. L. Ehrlich and C. L. Brierley (ed.), Microbial mineral recovery. McGraw Hill, New York, N.Y.

30. Mesbah, M., U. Premchandran, and W. B. Whitman. 1989. Precise measurement of the $\mathrm{G}+\mathrm{C}$ content of deoxyribonucleic acid by high-performance liquid chromatography. Int. J. Syst. Bacteriol. 39:159-167.

31. Miller, G. L. 1959. Use of dinitrosalicylic acid reagent for determination of reducing sugar. Anal. Chem. 31:426-428.

32. Patel, B. K. C., H. W. Morgan, and R. M. Daniel. 1985. Fervidobacterium nodosum gen. nov. and spec. nov., a new chemoorganotrophic, caldoactive, anaerobic bacterium. Arch. Microbiol. 141:63-69.

33. Rättö, M., I. M. Mathrani, B. Ahring, and L. Viikari. 1994. Application of thermostable xylanase of Dictyoglomus sp. in enzymatic treatment of kraft pulps. Appl. Microbiol. Biotechnol. 41:130-133.

34. Ravot, G., M. Magot, M.-L. Fardeau, B. K. C. Patel, G. Prensier, A. Egan, J.-L. Garcia, and B. Ollivier. 1995. Thermotoga elfii sp. nov., a novel thermophilic bacterium from an African oil-producing well. Int. J. Syst. Bacteriol, 45:308-314.

35. Ravot, G., B. Ollivier, M.-L. Fardeau, B. K. C. Patel, K. T. Andrews, M. Magot, and J.-L. Garcia. 1996. L-Alanine production from glucose fermentation by hyperthermophilic members of the domains Bacteria and Archaea: a remnant of an ancestral metabolism? Appl. Environ. Microbiol. 62:26572659.

36. Ravot, G., B. Ollivier, M. Magot, B. K. C. Patel, J.-L. Crolet, M.-L. Fardeau, and J.-L. Garcia. 1995. Thiosulfate reduction, an important physiological feature shared by members of the order Thermotogales. Appl. Environ. Microbiol. 61:2053-2055.

37. Ravot, G., B. Ollivier, B. K. C. Patel, M. Magot, and J.-L. Garcia. 1996 Emended description of Thermosipho africanus as a carbohydrate-fermenting species using thiosulfate as an electron acceptor. Int. J. Syst. Bacteriol. 46:321-323.

38. Redburn, A. C., and B. K. C. Patel. 1993. Phylogenetic analysis of Desulfotomaculum thermobenzoicum using polymerase chain reaction-amplified $16 \mathrm{~S}$ rRNA-specific DNA. FEMS Microbiol. Lett. 113:81-86.

39. Stetter, K. O., R. Huber, E. Blochl, M. Kurr, R. D. Eden, M. Fielder, H. Cash, and I. Vance. 1993. Hyperthermophilic Archaea are thriving in deep North Sea and Alaskan reservoirs. Nature 365:743-745.

40. Sunna, A., and G. Antranikian. 1996. Growth and production of xylanolytic enzymes by the extreme thermophilic anaerobic bacterium Thermotoga thermarum. Appl. Microbiol. Biotechnol. 45:671-676.

41. Vandamme, P., B. Pot, M. Gillis, P. De Vos, K. Kersters, and J. Swings. 1996 Polyphasic taxonomy, a consensus approach to bacterial systematics. Microbiol. Rev. 60:407-438.

42. Widdel, F. 1980. Anaerobacter abbau von fettsäuren und benzosäure durch neu isolierte arten sulfatreduzierender bakterien. Ph.D. thesis. University of Göttingen, Göttingen, Germany.

43. Wiegel, J., L. G. Ljungdahl, and J. R. Rawson. 1979. Isolation from soil and properties of the extreme thermophile Clostridium thermohydrosulfuricum. J. Bacteriol. 139:800-810.

44. Windberger, E., R. Huber, A. Trincone, H. Fricke, and K. O. Stetter. 1989. Thermotoga thermarum sp. nov. and Thermotoga neapolitana occurring in African continental solfataric springs. Arch. Microbiol. 151:506-512.

45. Winker, S., and C. R. Woese. 1991. A definition of the domains Archaea, Bacteria and Eucarya in terms of small subunit ribosomal RNA characteristics. Syst. Appl. Microbiol. 13:161-165. 